\title{
Evaluation of the MilkoScan FT 6000 Milk Analyzer for Determining the Freezing Point of Goat's Milk Under Different Analytical Conditions
}

\author{
A. Sánchez, ${ }^{*}$ D. Sierra,† C. Luengo,† J. C. Corrales, ${ }^{\star}$ C. de la Fe, ${ }^{\star}$ C. T. Morales, $†$ \\ A. Contreras, ${ }^{* 1}$ and C. Gonzaloł \\ *Departamento de Sanidad Animal, Facultad de Veterinaria, Universidad de Murcia, 30071 Murcia, Spain \\ †Laboratorio Agroalimentario y de Sanidad Animal, Consejería de Agricultura y Agua, Comunidad Autónoma de la Región de Murcia, \\ El Palmar, 30120 Murcia, Spain \\ łDepartamento de Producción Animal, Facultad de Veterinaria, Universidad de León, 24071 León, Spain
}

\section{ABSTRACT}

The aim of this research was to evaluate the MilkoScan FT 6000 (Foss Electric, Hillerød, Denmark) for determining the freezing point (FP) of goat's milk under different analytical conditions. The FP was determined in duplicate in 1,800 milk aliquots obtained from 45 bulk tank milk samples from 10 Murciano-Granadina goat herds, using the MilkoScan method and a reference thermistor cryoscopy method (Advanced Instrument Inc., Norwood, MA). Five different preservation strategies-no preservative, preservation with azidiol (0.006 or $0.018 \mathrm{~g}$ of sodium azide $/ 100 \mathrm{~mL}$ ), and preservation with bronopol $(0.020$ or $0.040 \mathrm{~g} / 100 \mathrm{~mL})$-were then used to preserve the milk. For each preservation strategy, 8 different amounts of water were added $(0,1,2$, $3,4,5,6$, or $7 \%$ total volume). The results obtained with each method under these 40 analytical conditions were examined by comparison of means, comparison of the standard deviations of repeatability $\left(\mathrm{s}_{\mathrm{r}}\right.$ and its relative value $\mathrm{s}_{\mathrm{r}} \%$ ), and a regression analysis. Under most analytical conditions, the FP was recorded as lower by the MilkoScan method, with a mean difference of $1.5 \mathrm{~m}^{\circ} \mathrm{C}$ compared with the reference method. Both methods showed similar repeatabilities (the overall $\mathrm{s}_{\mathrm{r}} \%$ was $0.22 \%$ for the MilkoScan method and $0.20 \%$ for the reference method). In comparisons of the 2 methods, the highest regression coefficients were obtained with aliquots containing $>3 \%$ added water. The best regression coefficients ( 0.85 to 1.02 ) were obtained for milk samples preserved with bronopol at $0.020 \mathrm{~g} / 100 \mathrm{~mL}$. These results allow the MilkoScan method to be used with goat's milk for screening purposes. The factors of added water, preservative, analytical method, lactose concentration, and the effect of the bulk tank milk sample within each lactose group contributed significantly

Received January 19, 2007.

Accepted March 8, 2007.

${ }^{1}$ Corresponding author: acontrer@um.es to the observed variation in FP. For practical purposes, either of the bronopol concentrations could be used when determining the FP of goat's milk with the methods tested. However, the increase in the concentration of sodium azide in the azidiol formula contributed to an important reduction in the FP recorded. Thus, the type and concentration of preservative should be taken into account when interpreting FP values.

Key words: goat milk, freezing point, MilkoScan, milk preservative

\section{INTRODUCTION}

The freezing point (FP) of milk is measured to determine the presence of added water in the bulk tank milk because of certain milking operations or as a sign of fraud. European law earlier established that heattreated cow's milk for human consumption should have an FP no higher than $-520 \mathrm{~m}^{\circ} \mathrm{C}$ (Council Directive 92/ 46/ECC; European Community, 1992). However, given the variation possible, Council Regulation no. 2597 (European Community, 1997) determined that such milk should have an FP close to the mean FP for raw milk in the collection region. Recent years have seen an increase in mean bulk tank cow's milk FP values because of changes in milking and cleaning methods (Slaghuis, 2001). Official monitoring of milk for added water should therefore take into account the unavoidable addition of water to each type of drinking milk, the natural variation in raw milk composition, and decisions on acceptability (based on statistical procedures; Glaeser, 2003). This is particularly important because FP is one of the factors taken into account in payment-by-quality schemes for cow's milk (Van Crombrugge, 2003) and goat's milk (Pirisi et al., 2007).

The thermistor cryoscope method, as defined by International Dairy Federation standard 108:2002/ISO 5764 (IDF, 2002), is the reference method for the determination of milk FP. This method is based on supercooling and crystallizing the milk; the FP is reached 
when the temperature of the frozen milk does not change by more than $0.5 \mathrm{~m}^{\circ} \mathrm{C}$ for $20 \mathrm{~s}$. Most payment-byquality schemes and dairy herd improvement programs rely on analyses involving a combined instrument that can both perform SCC and determine milk composition. These instruments can handle large numbers of samples, are fully automatic, and provide cost-effective and rapid determinations. More recent tools for determining milk composition include midrange infrared analyzers that use Fourier transform infrared technology. This allows more detailed spectral information to be obtained via the use of calibration procedures. The infrared attenuation and electrical conductivity of the milk are determined for the quantitative assessment of any extraneous water; the results can also be used for predicting the depression of the FP according to a patented method (Arnvidarson et al., 1998). The information available on the precision of these methods shows them to be very useful in the determination of FP in cow's milk (Van Crombrugge, 2003). However, none have been assessed for the determination of FP in goat's milk. Because of the concentration of watersoluble constituents of goat's milk, the FP of this milk is lower than that of cow's milk. Information regarding the overall accuracy of goat's milk FP determinations by instrumental methods could help optimize this kind of analysis.

In some countries, preservatives are added to milk samples before the testing associated with the payment-by-quality schemes, the official control of milk quality, and dairy herd improvement programs. Currently, a number of preservation strategies are used with milk samples destined to undergo SCC analysis using fluoro-opto-electronic counters (IDF, 2006) as well as in the determination of milk fat, protein, and lactose contents by midinfrared measurements (IDF, 2000). This use of preservatives has been identified as introducing variation into the results obtained with cow's milk (Bertrand, 1996). Recent studies on sheep's milk (Gonzalo et al., 2003, 2004; Martínez et al., 2003) have established the effects of preservatives, as well as other factors affecting the analytical conditions, on the overall accuracy of the different instruments used in SCC analysis. The effect of these preservatives on goat's milk SCC and the milk composition values obtained with the CombiFoss 6000 FC apparatus (Foss Electric, Hillerød, Denmark) have also been studied (Sánchez et al., 2005). Among the analytical conditions that affect goat's milk FP determinations, the latter study took into account the preservative used, the storage temperature (refrigeration and freezing), the age of the milk, and the interactions of these factors. Because preservatives are widely used in the preparation of milk samples in dairy laboratories, the effects of their different con- centrations on FP should be taken into account when checking for the addition of water to milk. In this sense, preservative use supposes a solute addition to the milk, so its effects could be of interest for interpreting the FP results.

Standard 128A of the IDF (1999) defines the overall accuracy of the instrumental methods available for the analysis of milk, comparing them with reference methods. This standard could be used in attempts to evaluate the accuracy of instrumental methods for determining the FP of goat's milk. Knowledge of the regression deviations and mean biases of goat's milk FP determination methods, as well as the effect of analytical conditions, are essential if intra- and interlaboratory quality control tests are to be performed.

The MilkoScan FT 6000 (Foss Electric) is based on Fourier transform infrared technology and provides a wide range of compositional parameters including fat, protein, lactose, solids, CN, FFA, urea, and FP depression. The aims of the present study were to determine the overall accuracy of the MilkoScan FT 6000 method for determining the FP in goat's milk, by comparing it with the reference thermistor cryoscope method under different analytical conditions, and to study the influence of different preservation strategies on the FP of goat's milk with and without experimentally added water.

\section{MATERIALS AND METHODS}

Forty-five 1,000-mL bulk tank milk samples were obtained by machine milking of 10 herds of MurcianoGranadina goats over their October to May lactation period. All samples were kept at $4^{\circ} \mathrm{C}$ and immediately transported to the laboratory (Laboratorio Agroalimentario y de Sanidad Animal, Murcia, Spain). Each sample was divided into forty $20-\mathrm{mL}$ aliquots $(\mathrm{n}=$ 1,800 ), and these were assigned to different experimental groups according to the amount of water to be added $(0,1,2,3,4,5,6$, and $7 \%$ total volume) and the preservative to be used: no preservative (NP), preservation with azidiol (0.006 or $0.018 \mathrm{~g}$ of sodium azide/100 mL, AZ6 and AZ18, respectively), and preservation with bronopol $(0.020$ or $0.040 \mathrm{~g} / 100 \mathrm{~mL}, \mathbf{B R 2 0}$ and BR40, respectively). A total of 40 analytical conditions were therefore examined by each method, according to the combination of preservation strategy and the amount of water added.

For the preparation of AZ6, $1.8 \mathrm{~g}$ of sodium azide, $0.075 \mathrm{~g}$ of chloramphenicol, $1 \mathrm{~mL}$ of ethanol, and $4.5 \mathrm{~g}$ of sodium citrate pentahydrate were dissolved in 100 $\mathrm{mL}$ of distilled water, to which $0.035 \mathrm{~g}$ of bromophenol blue was added as a colorant. The AZ18 was prepared using 3 times the concentration of sodium azide $(5.4 \mathrm{~g})$. The BR20 was prepared by dissolving $5 \mathrm{~g}$ of 2-bromo- 
Table 1. Composition of the bulk tank milk samples (analyses were performed in duplicate)

\begin{tabular}{lcccrr}
\hline Item & $\mathrm{n}$ & Mean & $\mathrm{SD}$ & Minimum & Maximum \\
\hline Freezing point, ${ }^{1} \mathrm{~m}^{\circ} \mathrm{C}$ & 45 & -553 & 6.8 & -537 & -568 \\
SCC, $\times 10^{3}$ cells $/ \mathrm{mL}$ & 45 & 1,562 & 856 & 372 & 4,724 \\
Nonfat DM, \% & 45 & 9.148 & 0.335 & 8.560 & 10.450 \\
DM, \% & 45 & 14.815 & 0.978 & 12.620 & 17.600 \\
Fat, \% & 45 & 5.711 & 0.740 & 3.830 & 7.150 \\
Total protein, \% & 45 & 3.655 & 0.314 & 3.100 & 4.910 \\
Lactose, \% & 45 & 4.930 & 0.140 & 4.650 & 5.190 \\
Lactose group 1, \% & 15 & 4.774 & 0.072 & 4.650 & 4.860 \\
Lactose group 2, \% & 15 & 4.932 & 0.039 & 4.880 & 4.990 \\
Lactose group 3, \% & 15 & 5.083 & 0.063 & 5 & 5.190 \\
\hline
\end{tabular}

${ }^{1}$ Reference method.

2-nitro-1,3-propanediol (Sigma-Aldrich, St. Louis, MO, reference 134708) in $100 \mathrm{~mL}$ of distilled water, and adding $0.05 \mathrm{~g}$ of methylene blue as a colorant. The BR40 was prepared using double the concentration of bronopol (BR, $10 \mathrm{~g})$. Preservatives were added at 80 and 66 $\mu \mathrm{L} / 20 \mathrm{~mL}$ of milk for BR and azidiol (AZ), respectively.

Milk composition (fat, total protein, lactose, and total solids) and the SCC of the bulk tank milk samples were determined using a CombiFoss 6000 FC apparatus (Foss Electric). This combines the MilkoScan FT 6000 Fourier transform infrared spectrometer and the Fossomatic FC flow cytometry somatic cell counter. Before testing, milk aliquots were heated to $40^{\circ} \mathrm{C}$ for $20 \mathrm{~min}$ (Sierra et al., 2006). Before and during the experiments, the equipment was subjected to interlaboratory quality control tests by a reference laboratory (Cecalait, Poligny, France). Table 1 shows the results obtained for the original bulk tank milk samples.

All milk aliquots were stored at $4^{\circ} \mathrm{C}$ until $\mathrm{FP}$ analysis, which was always performed within $24 \mathrm{~h}$ of collection. The FP values of each aliquot were determined in duplicate by both the reference method (IDF, 2002), which uses a thermistor cryoscope (Advanced Cryoscope, model 4D3; Advanced Instrument Inc.), and the MilkoScan method. The thermistor cryoscope was used in the ISO 5764 plateau-seeking mode according to the IDF standard 108:2002/ISO 5764 (IDF, 2002). Before and during the experiment, the thermistor cryoscope was subjected to calibration using standard $\mathrm{NaCl}$ solutions according to the international standard (IDF, 2002). The calibration of the MilkoScan apparatus was performed using modified goat's milk samples in which the reference FP values were determined by the thermistor cryoscope (range -490 to $-590 \mathrm{~m}^{\circ} \mathrm{C}$ ). A total of 7,200 FP values were finally processed. The FP results were expressed in millicelsius according to the international standard (IDF, 2002).

\section{Statistical Analyses}

The results obtained by the 2 methods under the different analytical conditions were examined by the comparison of means and standard deviations of repeatability, and by regression analysis. Means were compared using the GLM procedure in the SAS v. 6.11 software package (SAS Institute, 1996). The statistical model used for the latter was

$$
\mathrm{Y}_{\mathrm{ijk}}=\mu+\mathrm{A}_{\mathrm{i}}+\mathrm{B}_{\mathrm{j}}+\mathrm{e}_{\mathrm{ijk}}
$$

where $Y_{i j k}$ is the dependent variable, that is, the freezing point $\left(\mathrm{m}^{\circ} \mathrm{C}\right), \mu$ is the mean, $A_{i}$ is the effect of the 80 (40 conditions, 2 methods) previously defined analytical conditions, $B_{j}$ is the effect of the bulk tank milk sample $(n=45)$, and $\mathrm{e}_{\mathrm{ijk}}$ is the residual effect ( 2 replicates were considered because the analytical determinations were performed in duplicate).

For each analytical condition, the standard deviation of repeatability $\left(\mathrm{s}_{\mathrm{r}}\right.$ and its relative value $\mathrm{s}_{\mathrm{r}} \%=\mathrm{s}_{\mathrm{r}} \times 100 /$ $\overline{\mathrm{x}}$, where $\overline{\mathrm{x}}$ is the arithmetic mean of $\mathrm{FP}$ ) was calculated according to IDF standard 128A (IDF, 1999) using the formula

$$
\mathrm{S}_{\mathrm{r}}=\left(\frac{1}{2 \mathrm{q}} \sum_{\mathrm{i}=1}^{\mathrm{q}} \mathrm{w}_{\mathrm{i}}^{2}\right)^{1 / 2},
$$

where $\mathrm{q}$ is the number of samples, and $\mathrm{w}_{\mathrm{i}}$ is the absolute difference between duplicate results of the FP determination methods.

Linear regression was performed to establish the relationship between the reference and MilkoScan methods; all 40 analytical conditions were taken into account. The corresponding intercept (a), the coefficient of regression (b), and the coefficient of determination $\left(R^{2}\right)$ were estimated in all cases by using PROC REG (SAS Institute, 1996).

The GLM procedure (SAS Institute, 1996) was also used to study the fixed effects of the different variables using the model

$$
\begin{aligned}
& \mathrm{Y}_{\mathrm{ijklm}}=\mu+\mathrm{W}_{\mathrm{i}}+\mathrm{P}_{\mathrm{j}}+\mathrm{M}_{\mathrm{k}}+\mathrm{L}_{\mathrm{l}}+\mathrm{B}_{\mathrm{m}(\mathrm{l})} \\
& +\mathrm{WP}_{\mathrm{ij}}+\mathrm{WM}_{\mathrm{ik}}+\mathrm{PM}_{\mathrm{jk}}+\mathrm{WPM}_{\mathrm{ijk}}+\mathrm{e}_{\mathrm{ijklm}} \text {, } \\
& \text { Journal of Dairy Science Vol. } 90 \text { No. 7, } 2007
\end{aligned}
$$


where $Y_{\mathrm{ijklm}}$ is the dependent variable, that is, the freezing point $\left(\mathrm{m}^{\circ} \mathrm{C}\right), \mu$ is the mean, $\mathrm{W}_{\mathrm{i}}$ is the effect of the added water (8 classes: $0,1,2,3,4,5,6$, and $7 \%$ ), $\mathrm{P}_{\mathrm{j}}$ is the effect of the preservative (5 classes: NP, BR20, BR40, AZ6, and AZ18), $\mathrm{M}_{\mathrm{k}}$ is the analytical method (2 classes: instrumental and reference methods); $\mathrm{L}_{1}$ is the lactose group ( 3 classes; Table 1 ), $\mathrm{B}_{\mathrm{m}(1)}$ is the effect of the bulk tank milk sample within each lactose group, $\mathrm{WP}_{\mathrm{ij}}$ is the effect of the interaction of added water $\times$ preservative, $\mathrm{WM}_{\mathrm{ik}}$ is the effect of the interaction of added water $\times$ analytical method, $\mathrm{PM}_{\mathrm{jk}}$ is the effect of the interaction preservative $\times$ analytical method, $\mathrm{WPM}_{\mathrm{ijk}}$ is the effect of the interaction of added water $\times$ preservative $\times$ analytical method, and $e_{i j k l m}$ is the random residual effect. Validity parameters (sensibility, specificity, positive predictive value, and negative predictive value) were obtained following the recommendations of Thrusfield (1995).

\section{RESULTS AND DISCUSSION}

Table 2 compares the mean FP values obtained by the reference and MilkoScan methods under the 40 analytical conditions tested. Those obtained by the latter method (from -564 to $-512 \mathrm{~m}^{\circ} \mathrm{C}$ ) were lower $(P<$ 0.05 ) than those obtained by the reference method (from -565 to $-509 \mathrm{~m}^{\circ} \mathrm{C}$ ) under most of the analytical conditions studied. The mean difference between the FP values obtained with each method was $1.5 \mathrm{~m}^{\circ} \mathrm{C}$. The FP differences between methods increased slightly with the amount of water added. Within each water percentage group (except for the 1\% group), the greatest differences between the 2 methods $(P<0.001)$ were obtained among unpreserved samples $\left(2.1\right.$ and $3.7 \mathrm{~m}^{\circ} \mathrm{C}$ for the 2 and $7 \%$ added water samples, respectively). Because the FP differences between methods were in all the analytical conditions studied lower than that caused for water addition, these differences could have little significance in the practical interpretation of FP.

Table 2 shows the standard deviation of repeatability $\left(\mathrm{s}_{\mathrm{r}}\right.$ and $\left.\mathrm{s}_{\mathrm{r}} \%\right)$ for the FP for each method under the analytical conditions studied. The reference method showed a lower mean $\mathrm{s}_{\mathrm{r}} \%(0.20 \%)$ than that recorded in the interlaboratory analysis performed with raw cow's milk (0.25) and that shown in Annex A of IDF standard 108:2002/ISO 5764 (IDF, 2002). The latter study involved laboratories in 13 countries, showing $\mathrm{s}_{\mathrm{r}}$ values ranging between 1.1 and 1.4 (mean 1.3). In the present experiment, the $\mathrm{s}_{\mathrm{r}}$ values obtained with the reference method were slightly lower, varying from 0.901 to 1.256 $\mathrm{m}^{\circ} \mathrm{C}$. The MilkoScan method gave a mean $\mathrm{s}_{\mathrm{r}} \%$ of $0.22 \%$, slightly higher than that obtained with the reference method. Despite the discrepancy shown by the AZ18 samples with no added water $\left(\mathrm{s}_{\mathrm{r}}=2.85\right)$, the $\mathrm{s}_{\mathrm{r}}$ values obtained with the MilkoScan method (from 0.82 to 1.48 $\mathrm{m}^{\circ} \mathrm{C}$ ) were similar to those recorded by other authors (Van Crombrugge, 2003). The small differences seen in repeatability under the different analytical conditions suggested that this parameter was not modified by the addition of water or preservatives in either method.

Table 3 shows the results of the regression analysis between the reference and MilkoScan methods under each analytical condition studied. The highest correlation coefficients were obtained when testing AZ6 samples with $1 \%$ added water $(r=0.947)$ and BR20 samples with no added water (0.946). In the samples with 0 and $1 \%$ added water, the slope and intercept for all combinations of conditions were different $(P<0.05)$ to 1.00 and 0.00 , respectively. However, in milk aliquots with $>3 \%$ added water, neither the slope nor intercept differed $(P>0.05)$ from the theoretical values. Moreover, the best regression coefficients between the 2 methods were obtained in the milk aliquots with high added water content $(b=0.906$ to 1.051$)$, along with the best intercept values ( $\mathrm{a}=-0.55$ to -51.26$)$, except when the milk was preserved with AZ6 and contained $7 \%$ added water. The greater precision obtained between the methods in the samples with $>3 \%$ added water agrees with results obtained with the MilkoScan 4000 (Foss Electric), the calibration of which with cow's milk samples containing added water led to better stability than calibrations based on data from natural samples (Arnvidarson et al., 1998). Within each percentage added water group, the most reliable analytical conditions were obtained with samples preserved with BR20; in all cases, the $b$ values increased and the a values decreased (Table 3). The regression analysis suggests that the added water content detected by the MilkoScan method should be confirmed using the reference method, particularly when low levels of added water are suspected. For practical purposes, given the small difference between the results obtained with the studied methods, the need for such confirmation would depend on the design of the FP-associated payment scheme (penalty level, number and mean of FP results by time unit, etc.). Currently, of the 6 European countries that use midinfrared analyzers or Fourier transform infrared instruments for determining FP in cow's milk quality payment schemes, 4 are contemplating an FP requiring confirmation with the cryoscopic method that is lower than the penalty level, and 2 do not undertake confirmation with the reference method (Van Crombrugge, 2003). In goat's milk, reference levels vary between $-530 \mathrm{~m}^{\circ} \mathrm{C}$ in the United States and $-550 \mathrm{~m}^{\circ} \mathrm{C}$ in Greece (Pirisi et al., 2007); France uses an intermediate value of $-545 \mathrm{~m}^{\circ} \mathrm{C}$ (Poitou Charentes region; Raynal-Ljutovac et al., 2005), and the FP limit used in Murcia region (the main Spanish area producing milk 
Table 2. Least squares means of the freezing point $\left(\mathrm{m}^{\circ} \mathrm{C}\right)$ and standard deviations of repeatability $\left(\mathrm{s}_{\mathrm{r}}\right.$ and $\mathrm{s}_{\mathrm{r}} \%$ ) for each of the 40 analytical conditions examined with the instrumental (IM) and reference (RM) methods

\begin{tabular}{|c|c|c|c|c|c|c|c|}
\hline $\begin{array}{l}\text { Analytical } \\
\text { condition }^{1}\end{array}$ & $\begin{array}{c}\mathrm{IM}^{2} \\
\mathrm{LSM}^{4}{ }^{4} \\
\mathrm{~m}^{\circ} \mathrm{C}\end{array}$ & $\begin{array}{c}\mathrm{RM}^{3} \\
\mathrm{LSM}^{4}{ }^{4} \\
\mathrm{~m}^{\circ} \mathrm{C}\end{array}$ & $P$ & $\begin{array}{c}\mathrm{IM} \mathrm{s}_{\mathrm{r}}, \\
\mathrm{m}^{\circ} \mathrm{C}\end{array}$ & $\underset{\%}{\mathrm{IM} \mathrm{s}_{\mathrm{r}}}$ & $\begin{array}{c}\mathrm{RM} \mathrm{s}_{\mathrm{r}}, \\
\mathrm{m}^{\circ} \mathrm{C}\end{array}$ & $\underset{\%}{\mathrm{RM} \mathrm{s}_{\mathrm{r}},}$ \\
\hline $0-\mathrm{NP}$ & $-555^{\mathrm{a}}$ & $-553^{\mathrm{a}}$ & $<0.001$ & 1.179 & 0.212 & 1.179 & 0.213 \\
\hline 0 -BR20 & -554 & $-553^{a}$ & $<0.01$ & 0.894 & 0.161 & 1.135 & 0.205 \\
\hline $0-B R 40$ & $-555^{\mathrm{a}}$ & -555 & NS & 0.843 & 0.152 & 1.116 & 0.201 \\
\hline $0-A Z 6$ & -559 & $-559^{b}$ & NS & 0.989 & 0.177 & 1.225 & 0.219 \\
\hline 0-AZ18 & -564 & -565 & $<0.001$ & 2.846 & 0.506 & 1.234 & 0.218 \\
\hline $1-\mathrm{NP}$ & $-547^{b}$ & $-547^{\mathrm{d}}$ & NS & 1.909 & 0.349 & 1.130 & 0.207 \\
\hline 1-BR20 & -549 & $-547^{\mathrm{de}}$ & $<0.001$ & 1.033 & 0.189 & 1.011 & 0.185 \\
\hline 1-BR40 & -550 & -549 & NS & 0.937 & 0.170 & 0.907 & 0.165 \\
\hline 1-AZ6 & -553 & $-552^{\mathrm{ac}}$ & $<0.05$ & 1.065 & 0.193 & 1.065 & 0.193 \\
\hline 1-AZ18 & -558 & $-558^{\mathrm{b}}$ & NS & 1.130 & 0.203 & 1.160 & 0.208 \\
\hline $2-\mathrm{NP}$ & $-543^{\mathrm{c}}$ & $-541^{f}$ & $<0.001$ & 1.418 & 0.261 & 1.269 & 0.235 \\
\hline 2-BR20 & $-542^{\mathrm{c}}$ & $-540^{\mathrm{fg}}$ & $<0.001$ & 0.913 & 0.168 & 1.043 & 0.193 \\
\hline 2-BR40 & -544 & -543 & $<0.05$ & 0.85 & 0.156 & 1.085 & 0.200 \\
\hline 2-AZ6 & $-547^{\mathrm{b}}$ & $-546^{\mathrm{e}}$ & $<0.01$ & 1.179 & 0.216 & 1.135 & 0.208 \\
\hline 2-AZ18 & -552 & $-552^{\mathrm{c}}$ & NS & 1.197 & 0.217 & 1.256 & 0.228 \\
\hline $3-\mathrm{NP}$ & $-537^{\mathrm{d}}$ & $-534^{\mathrm{im}}$ & $<0.001$ & 1.386 & 0.258 & 1.265 & 0.237 \\
\hline 3-BR20 & -536 & $-534^{\mathrm{mj}}$ & $<0.001$ & 0.869 & 0.162 & 1.197 & 0.224 \\
\hline 3-BR40 & $-538^{\mathrm{d}}$ & $-536^{\mathrm{i}}$ & $<0.01$ & 0.96 & 0.178 & 1.059 & 0.198 \\
\hline 3-AZ6 & -541 & $-540^{\text {gh }}$ & $<0.01$ & 1.476 & 0.273 & 1.054 & 0.195 \\
\hline 3-AZ18 & -546 & -545 & $<0.05$ & 1.563 & 0.286 & 0.901 & 0.165 \\
\hline 4-NP & $-531^{\mathrm{ef}}$ & $-528^{\mathrm{k}}$ & $<0.001$ & 1.354 & 0.255 & 1.282 & 0.243 \\
\hline 4-BR20 & $-531^{\mathrm{f}}$ & $-528^{\mathrm{kl}}$ & $<0.001$ & 0.937 & 0.177 & 0.983 & 0.186 \\
\hline 4-BR40 & $-532^{\mathrm{e}}$ & -530 & $<0.001$ & 0.823 & 0.155 & 1.017 & 0.192 \\
\hline 4-AZ6 & -536 & $-534^{\mathrm{ij}}$ & $<0.001$ & 1.229 & 0.230 & 1.329 & 0.249 \\
\hline 4-AZ18 & -540 & $-540^{\mathrm{h}}$ & NS & 1.300 & 0.241 & 0.989 & 0.183 \\
\hline 5-NP & $-525^{\mathrm{g}}$ & $-522^{\circ}$ & $<0.001$ & 1.321 & 0.252 & 1.164 & 0.223 \\
\hline 5-BR20 & $-524^{\mathrm{h}}$ & $-521^{\mathrm{n}}$ & $<0.001$ & 0.843 & 0.161 & 0.983 & 0.189 \\
\hline 5-BR40 & $-525^{\mathrm{g}}$ & -524 & $<0.001$ & 1.374 & 0.262 & 1.193 & 0.228 \\
\hline $5-\mathrm{AZ} 6$ & $-530^{\mathrm{f}}$ & $-528^{\mathrm{l}}$ & $<0.001$ & 1.183 & 0.223 & 1.038 & 0.197 \\
\hline 5-AZ18 & -534 & $-533^{j}$ & NS & 1.022 & 0.191 & 1.027 & 0.193 \\
\hline 6-NP & $-519^{i}$ & $-516^{p}$ & $<0.001$ & 1.308 & 0.252 & 1.256 & 0.243 \\
\hline 6-BR20 & -518 & $-516^{p}$ & $<0.001$ & 0.972 & 0.188 & 1.111 & 0.215 \\
\hline 6-BR40 & $-519^{\mathrm{i}}$ & -518 & $<0.001$ & 0.850 & 0.164 & 1.006 & 0.194 \\
\hline 6-AZ6 & $-523^{\mathrm{h}}$ & $-521^{\text {no }}$ & $<0.001$ & 1.022 & 0.195 & 0.901 & 0.173 \\
\hline 6-AZ18 & -528 & $-528^{\mathrm{l}}$ & NS & 0.989 & 0.187 & 0.943 & 0.179 \\
\hline 7-NP & $-513^{j}$ & $-510^{q}$ & $<0.001$ & 1.238 & 0.241 & 1.059 & 0.208 \\
\hline 7-BR20 & -512 & $-509^{q}$ & $<0.001$ & 0.989 & 0.193 & 1.164 & 0.229 \\
\hline 7-BR40 & $-513^{\mathrm{sj}}$ & -511 & $<0.001$ & 0.876 & 0.171 & 0.955 & 0.187 \\
\hline 7-AZ6 & -517 & $-516^{p}$ & $<0.01$ & 1.033 & 0.200 & 0.919 & 0.178 \\
\hline 7-AZ18 & -522 & $-521^{\mathrm{n}}$ & $<0.05$ & 0.949 & 0.182 & 0.972 & 0.187 \\
\hline
\end{tabular}

${ }^{\mathrm{a}-\mathrm{q}}$ Means within the same column with the same superscript letter do not differ $(P<0.05)$.

${ }^{1} 0-7=$ percentage of added water (total volume); $\mathrm{NP}=$ no preservative; $\mathrm{BR} 20=$ bronopol with $0.020 \mathrm{~g} /$ $100 \mathrm{~mL}$; BR40 = bronopol with $0.040 \mathrm{~g} / 100 \mathrm{~mL}$; AZ6 = azidiol with $0.006 \mathrm{~g}$ of sodium azide $/ 100 \mathrm{~mL}$; AZ18 = azidiol with $0.018 \mathrm{~g}$ of sodium azide $/ 100 \mathrm{~mL}$.

${ }^{2}$ MilkoScan FT 6000 (Foss Electric, Hillerød, Denmark).

${ }^{3}$ Thermistor cryoscope (Advanced Cryoscope, model 4D3, Advanced Instrument Inc., Norwood, MA).

${ }^{4} \mathrm{SE}$ of $\mathrm{LSM}=0.262$.

goat) is $-540 \mathrm{~m}^{\circ} \mathrm{C}$. We had compared the MilkoScan method with the reference method for the detection of added water, using a limit of $-540 \mathrm{~m}^{\circ} \mathrm{C}$, and the results showed good validity parameters (sensibility $=92.77 \%$, specificity $=98.43$, positive predictive value $=98.85 \%$, negative predictive value $=90.36 \%$ ), indicating good ability of the instrumental method for screening the FP in goat's milk.

The factors of added water, preservation, analytical method, lactose concentration, effect of the bulk tank milk sample within lactose group, and their interactions, contributed significantly to the variation in the FP observed (Table 4). The addition of water was the main factor that affected FP, as expected. Mean FP values varied from $-557 \pm 0.083 \mathrm{~m}^{\circ} \mathrm{C}$ to $-514 \pm 0.083$ $\mathrm{m}^{\circ} \mathrm{C}$ in the samples with 0 and $7 \%$ added water, increasing by $6 \mathrm{~m}^{\circ} \mathrm{C}$ for each percentage point. The results obtained agree with mathematical estimations for goat's milk FP (Szijarto and van de Voort, 1983) and allow the detection of fraudulent water addition. In 
Table 3. Coefficients of regression (b), intercept (a), and $\mathrm{R}^{2}$ values based on regression analyses for freezing point values $\left(\mathrm{m}^{\circ} \mathrm{C}\right)$ obtained by the reference and MilkoScan methods under different analytical conditions

\begin{tabular}{|c|c|c|c|c|c|}
\hline $\begin{array}{l}\text { Analytical } \\
\text { condition }^{1}\end{array}$ & $\mathrm{~b}$ & $\mathrm{SE}$ & $\mathrm{a}$ & $\mathrm{SE}$ & $\mathrm{R}^{2}$ \\
\hline $0-\mathrm{NP}$ & $0.831 * * *$ & 0.051 & $-95.73^{* *}$ & 28.28 & 0.860 \\
\hline 0-BR20 & $0.880 * *$ & 0.046 & $-67.10^{*}$ & 25.59 & 0.894 \\
\hline 0 -BR40 & $0.786 * * *$ & 0.043 & $-118.85^{* * *}$ & 23.96 & 0.885 \\
\hline $0-\mathrm{AZ6}$ & $0.806 * * *$ & 0.045 & $-109^{\text {**** }}$ & 25.22 & 0.881 \\
\hline $0-A Z 18$ & $0.804 * *$ & 0.064 & $-109.57 * *$ & 36.24 & 0.785 \\
\hline 1-NP & $0.864 *$ & 0.058 & $-74.71^{*}$ & 31.65 & 0.838 \\
\hline 1-BR20 & $0.849 * *$ & 0.058 & $-84.22 *$ & 31.62 & 0.834 \\
\hline 1-BR40 & $0.632^{* * *}$ & 0.054 & $-202.25^{* * *}$ & 29.66 & 0.761 \\
\hline 1-AZ6 & $0.803 * * *$ & 0.041 & -109.90 *** & 22.90 & 0.897 \\
\hline 1-AZ18 & $0.774 * * *$ & 0.051 & -126.19 *** & 28.41 & 0.843 \\
\hline 2-NP & $0.915^{\mathrm{NS}}$ & 0.055 & $-48.01^{\mathrm{NS}}$ & 29.84 & 0.865 \\
\hline 2-BR20 & $0.893^{\mathrm{NS}}$ & 0.063 & $-59.77^{\mathrm{NS}}$ & 34.24 & 0.822 \\
\hline 2-BR40 & $0.842^{* *}$ & 0.057 & $-86.45^{* *}$ & 30.78 & 0.838 \\
\hline 2-AZ6 & $0.838 * * *$ & 0.047 & $-89.76^{* *}$ & 25.58 & 0.882 \\
\hline 2-AZ18 & $0.786 * * *$ & 0.057 & $-118.02^{* * *}$ & 31.37 & 0.817 \\
\hline $3-\mathrm{NP}$ & $0.931^{\mathrm{NS}}$ & 0.06 & $-39.58^{\mathrm{NS}}$ & 32.01 & 0.848 \\
\hline 3-BR20 & $9.444^{\mathrm{NS}}$ & 0.062 & $-32.21^{\mathrm{NS}}$ & 33.47 & 0.841 \\
\hline 3-BR40 & $0.886^{\mathrm{NS}}$ & 0.069 & $-62.30^{\mathrm{NS}}$ & 36.80 & 0.795 \\
\hline $3-\mathrm{AZ} 6$ & $0.893^{*}$ & 0.052 & $-59.19 *$ & 28.13 & 0.872 \\
\hline 3-AZ18 & $0.533 * * *$ & 0.079 & -255.28 *** & 43.03 & 0.515 \\
\hline $4-\mathrm{NP}$ & $0.945^{\mathrm{NS}}$ & 0.065 & $-32.90^{\mathrm{NS}}$ & 24.13 & 0.833 \\
\hline 4-BR20 & $0.971^{\mathrm{NS}}$ & 0.077 & $-17.53^{\mathrm{NS}}$ & 40.82 & 0.786 \\
\hline 4-BR40 & $0.957^{\mathrm{NS}}$ & 0.063 & $-23.09^{\mathrm{NS}}$ & 33.14 & 0.845 \\
\hline 4-AZ6 & $0.924^{\mathrm{NS}}$ & 0.059 & $-41.83^{\mathrm{NS}}$ & 31.48 & 0.851 \\
\hline 4-AZ18 & $0.906^{\mathrm{NS}}$ & 0.068 & $-51.26^{\mathrm{NS}}$ & 36.77 & 0.804 \\
\hline 5 -NP & $1.022^{\mathrm{NS}}$ & 0.075 & $8.08^{\mathrm{NS}}$ & 39.07 & 0.813 \\
\hline 5 -BR20 & $0.976^{\mathrm{NS}}$ & 0.061 & $-15.34^{\mathrm{NS}}$ & 31.81 & 0.856 \\
\hline 5-BR40 & $0.989^{\mathrm{NS}}$ & 0.07 & $-7.55^{\mathrm{NS}}$ & 36.73 & 0.822 \\
\hline $5-A Z 6$ & $0.936^{\mathrm{NS}}$ & 0.105 & $-36.27^{\mathrm{NS}}$ & 55.18 & 0.651 \\
\hline 5-AZ18 & $0.953^{\mathrm{NS}}$ & 0.063 & $-25.84^{\mathrm{NS}}$ & 33.63 & 0.842 \\
\hline 6-NP & $1.048^{\mathrm{NS}}$ & 0.075 & $20.84^{\mathrm{NS}}$ & 38.67 & 0.819 \\
\hline 6-BR20 & $1.004^{\mathrm{NS}}$ & 0.072 & $-0.55^{\mathrm{NS}}$ & 37.05 & 0.820 \\
\hline 6-BR40 & $1.011^{\mathrm{NS}}$ & 0.069 & $4.16^{\mathrm{NS}}$ & 35.46 & 0.835 \\
\hline 6-AZ6 & $0.995^{\mathrm{NS}}$ & 0.064 & $-4.86^{\mathrm{NS}}$ & 33.46 & 0.848 \\
\hline 6-AZ18 & $0.989^{\mathrm{NS}}$ & 0.072 & $-6.39^{\mathrm{NS}}$ & 38.14 & 0.813 \\
\hline 7-NP & $1.023^{\mathrm{NS}}$ & 0.069 & $7.79^{\mathrm{NS}}$ & 35.00 & 0.838 \\
\hline 7-BR20 & $1.019^{\mathrm{NS}}$ & 0.076 & $6.90^{\mathrm{NS}}$ & 38.45 & 0.809 \\
\hline 7-BR40 & $1.051^{\mathrm{NS}}$ & 0.073 & $24.14^{\mathrm{NS}}$ & 37.15 & 0.830 \\
\hline 7-AZ6 & $0.572 * * *$ & 0.093 & $-222.04 * * *$ & 47.85 & 0.469 \\
\hline 7-AZ18 & $0.951^{\mathrm{NS}}$ & 0.082 & $-26.24^{\mathrm{NS}}$ & 42.90 & 0.756 \\
\hline
\end{tabular}

${ }^{1} 0-7=$ percentage of added water (total volume); $\mathrm{NP}=$ no preservative; BR20 = bronopol with $0.020 \mathrm{~g} /$ $100 \mathrm{~mL}$; BR40 = bronopol with $0.040 \mathrm{~g} / 100 \mathrm{~mL}$; AZ6 = azidiol with $0.006 \mathrm{~g}$ of sodium azide $/ 100 \mathrm{~mL}$; AZ18 = azidiol with $0.018 \mathrm{~g}$ of sodium azide $/ 100 \mathrm{~mL}$.

$* P<0.05 ; * * P<0.01 ; * * * P<0001$.

addition, because automatic milking systems for cows increase the FP (Rasmussen et al., 2002), the monitoring of these values may be useful to both farmers and technicians when trying to determine the efficacy of milking and cleaning systems.

The effects of the different preservation strategies studied on the FP were different $(P<0.001)$. The smallest differences were obtained between the NP $(-533 \pm$ $\left.0.066 \mathrm{~m}^{\circ} \mathrm{C}\right)$ and BR20 and BR40 samples $(-532 \pm 0.066$ and $-534 \pm 0.066 \mathrm{~m}^{\circ} \mathrm{C}$, respectively). The lowest $\mathrm{FP}$ values were recorded with the AZ18 $\left(-543 \pm 0.066 \mathrm{~m}^{\circ} \mathrm{C}\right)$ and AZ6 samples $\left(-538 \pm 0.066 \mathrm{~m}^{\circ} \mathrm{C}\right)$. These lower FP of the preserved samples can be explained by changes in the osmolality of the milk attributable to the increase in the water-soluble constituents of the samples; this effect was similar in both analytical methods studied (Table 5). The results obtained agree with previous studies on goat's milk samples preserved with AZ (Sánchez et al., 2005). However, in goat's milk samples preserved with BR at the same concentration $(0.040 \mathrm{~g} / 100$ $\mathrm{mL}$ ), the reduction in FP was greater (mean reduction $26 \mathrm{~m}^{\circ} \mathrm{C}$ ) than that obtained in the present study. This might be explained by the fact that, in the present study, the BR was used in a watery solution, whereas Sánchez et al. (2005) used commercial BR tablets containing $0.30 \mathrm{mg}$ of natamycin/tablet (a tetraene-polyene 
Table 4. Analysis of variance of variations in freezing point

\begin{tabular}{lrrr}
\hline Source of variation & df & \multicolumn{1}{c}{$F$} & $P$ \\
\hline Water added & 7 & $32,424.9$ & $<0.0001$ \\
Preservative & 4 & $4,620.33$ & $<0.0001$ \\
Analytical method & 1 & 664.07 & $<0.0001$ \\
Lactose group & 2 & 331.81 & $<0.0001$ \\
Effect of bulk tank milk sample within lactose group & 42 & $1,119.47$ & $<0.0001$ \\
Water added $\times$ preservative & 28 & 1.70 & 0.0123 \\
Water added $\times$ analytical method & 7 & 15.73 & $<0.0001$ \\
Preservative $\times$ analytical method & 4 & 50.45 & $<0.0001$ \\
Water added $\times$ preservative $\times$ analytical method & 28 & 1.59 & 0.0244 \\
\hline
\end{tabular}

antibiotic derived from Streptomyces natalensis that possesses in vitro activity against a variety of yeast and filamentous fungi); this could have increased the watersoluble constituent content. The maximum concentration of preservatives is fixed by the IDF at $0.024 \mathrm{~g} / 100$ $\mathrm{mL}$ of sodium azide and $0.05 \mathrm{~g} / 100 \mathrm{~mL}$ of $\mathrm{BR}$ for SCC determinations (IDF, 2006), and at $0.03 \mathrm{~g} / 100 \mathrm{~mL}$ of sodium azide and 0.02 to $0.06 \mathrm{~g} / 100 \mathrm{~mL}$ of $\mathrm{BR}$ for the determination of fats, proteins, and lactose (IDF, 2000). The results showed that, for practical purposes, both BR concentrations can be used when determining the FP of goat's milk with either method studied. The sodium azide used was in the form of AZ (which contains sodium azide and chloramphenicol). This is used in payment-by-quality schemes when trying to determine the composition of the milk, SCC, and total bacteria count using the BactoScan method (Foss Electric). Recently, Elizondo et al. (2007) assessed the efficacy of different concentrations of the sodium azide in $\mathrm{AZ}$ preservative

Table 5. Least squares means of the freezing point according to the interaction of preservative $\times$ analytical method

\begin{tabular}{|c|c|c|}
\hline Analytical method & Preservative $^{1}$ & $\begin{array}{l}\mathrm{LSM}^{2} \\
\text { freezing } \\
\text { point, } \\
\mathrm{m}^{\circ} \mathrm{C}\end{array}$ \\
\hline Instrumental method ${ }^{3}$ & $\begin{array}{l}\text { NP } \\
\text { BR20 } \\
\text { BR40 } \\
\text { AZ6 } \\
\text { AZ18 }\end{array}$ & $\begin{array}{l}-534^{\mathrm{a}} \\
-533^{\mathrm{b}} \\
-534^{\mathrm{c}} \\
-538^{\mathrm{d}} \\
-543^{\mathrm{e}}\end{array}$ \\
\hline Reference method ${ }^{4}$ & $\begin{array}{l}\text { NP } \\
\text { BR20 } \\
\text { BR40 } \\
\text { AZ6 } \\
\text { AZ18 }\end{array}$ & $\begin{array}{l}-531^{\mathrm{f}} \\
-531^{\mathrm{g}} \\
-533^{\mathrm{b}} \\
-537^{\mathrm{b}} \\
-543^{\mathrm{i}}\end{array}$ \\
\hline
\end{tabular}

${ }^{\mathrm{a}-\mathrm{i}}$ Means with different superscripts differ $(P<0.05)$.

${ }^{1} \mathrm{NP}=$ no preservative; $\mathrm{BR} 20=$ bronopol with $0.020 \mathrm{~g} / 100 \mathrm{~mL}$; $\mathrm{BR} 40=$ bronopol with $0.040 \mathrm{~g} / 100 \mathrm{~mL} ; \mathrm{AZ6}=$ azidiol with $0.006 \mathrm{~g}$ of sodium azide $/ 100 \mathrm{~mL}$; AZ18 = azidiol with $0.018 \mathrm{~g}$ of sodium azide/ $100 \mathrm{~mL}$.

${ }^{2} \mathrm{SEM}$ of $\mathrm{LSM}=0.093$

${ }^{3}$ MilkoScan FT 6000 (Foss Electric, Hillerød, Denmark).

${ }^{4}$ Thermistor cryoscope (Advanced Cryoscope, model 4D3, Advanced Instrument Inc., Norwood, MA). when used for the preservation of sheep's milk, and found that a concentration of $0.006 \mathrm{~g}$ of sodium azide/ $100 \mathrm{~mL}$ allowed more precise evaluations of the bacteriological quality of raw milk. The results of the present work show that increasing the sodium azide concentration from 0.006 to $0.018 \mathrm{~g}$ of sodium azide $/ 100 \mathrm{~mL}$ in the AZ formula leads to an important reduction in FP values.

The effects of the preservatives and their different concentrations were similar with the different amounts of additional water (Figure 1), as recorded by both methods (Table 2). Therefore, the type of preservative used and its concentration should be taken into account in the interpretation of $\mathrm{FP}$ with the aim of avoiding misinterpretations of the presence of added water in preserved milk samples.

The lactose concentration showed small variations in the bulk tank samples over the lactation period, although the amounts present in the studied samples (Table 1) had a significant effect on the FP (Table 4). It is well known that the FP of milk depends on the concentration of water-soluble constituents and that the lactose concentration is the main constituent that explains the FP variation of the milk (Wheelock et al., 1965).

\section{CONCLUSIONS}

The high repeatability and reliable accuracy obtained under the different analytical conditions suggests that the MilkoScan method can be used for screening FP in bulk tank goat's milk samples. According to the regression analysis, the best analytical condition for FP determination when using the MilkoScan FT 6000 involved preservation with $\mathrm{BR}$ at $0.020 \mathrm{~g} / 100 \mathrm{~mL}$. An increasing sodium azide concentration in the $\mathrm{AZ}$ formula led to a strong reduction in the FP measured. Within each method, the FP of goat's milk must be interpreted by taking into account the type and concentration of the preservative used; if not, the effect of the preservative could lead to misinterpretations regarding the water content. The effects of the preservative and the added 


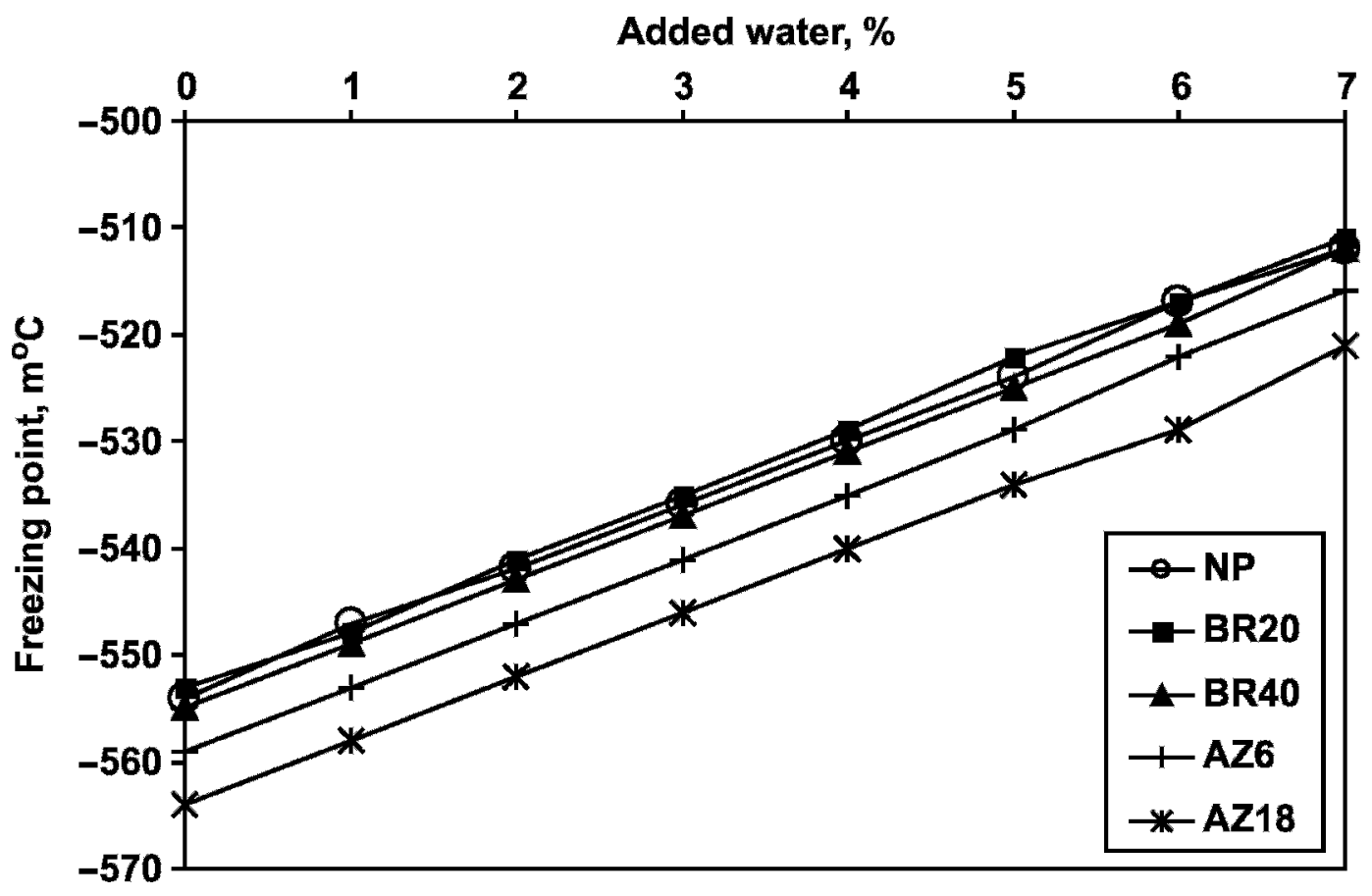

Figure 1. Least squares means of freezing points (milliCelsius) according to the interaction of added water $\times$ preservative $(\mathrm{NP}=\mathrm{no}$ preservative; $\mathrm{BR} 20=$ bronopol with $0.020 \mathrm{~g} / 100 \mathrm{~mL}$; BR40 = bronopol with $0.040 \mathrm{~g} / 100 \mathrm{~mL}$; AZ6 = azidiol with $0.006 \mathrm{~g}$ of sodium azide/100 $\mathrm{mL} ; \mathrm{AZ18}=$ azidiol with $0.018 \mathrm{~g}$ of sodium azide $/ 100 \mathrm{~mL}$ ).

water should also be taken into account in intra- and interlaboratory quality control.

\section{ACKNOWLEDGMENT}

This study was partly supported by project AGL200603105GAN, financed by the Dirección General de Investigación (Ministerio de Educación y Ciencia, Spain).

\section{REFERENCES}

Arnvidarson, B., L. Nygaard, and P. W. Hansen. 1998. Determination of extraneous water in milk samples, or the freezing point depression of milk samples. Foss Electric A/S Hillerød, Denmark. US Pat. No. 5,739,034. April 1998. Available: http://www.free patentsonline.com/5739034.html Accessed Nov. 23, 2006.

Bertrand, J. A. 1996. Influence of shipping container, preservative, and breed on analysis of milk components of shipped samples. J. Dairy Sci. 79:145-148.

European Community. 1992. Council Directive 92/46/EEC of 16 June 1992. Laying down the health rules for the production and placing on the market of raw milk, heat-treated milk and milk-based products. Off. J. Eur. Commun. 268:1-32.

European Community. 1997. Council Regulation (EC) No. 2597/1997 of 18 December 1997. Laying down additional rules on the common organization of the market in milk and milk products for drinking milk. Off. J. Eur. Commun. 351:13-15.

Elizondo, J., A. Aldunate, P. Ezcurra, I. Gallego, E. Saigos, E. Ulayar, and J. M. Izco. 2007. Efficiency of the proportion of azidiol on preservation in ewe's milk samples for analysis. Food Contr. 18:185-190

Gonzalo, C., J. C. Boixo, J. A. Carriedo, and F. San Primitivo. 2004. Evaluation of rapid somatic cell counters under different analytical conditions in ovine milk. J. Dairy Sci. 87:3623-3628.
Gonzalo, C., J. R. Martínez, J. A. Carriedo, and F. San Primitivo. 2003. Fossomatic cell-counting on ewe milk: Comparison with direct microscopy and study of variation factors. J. Dairy Sci. $86: 138-145$

Glaeser, H. 2003. Control of the water content of dairy productsDefinition of limits, consideration of process variation, official use of autocontrol data. Food Chem. 82:121-124.

IDF (International Dairy Federation). 1999. Definition and evaluation of the overall accuracy of indirect methods of milk analysis application to calibration procedure and quality control in the dairy laboratory. FIL-IDF Standard no. 128A. IDF, Brussels, Belgium.

IDF (International Dairy Federation). 2000. Whole milk, determination of milkfat, protein and lactose content. Guidance on the operation of mid-infrared instruments. FIL-IDF Standard no. 141C. IDF, Brussels, Belgium.

IDF (International Dairy Federation), 2002. Milk. Determination of freezing point. Thermistor cryoscope method (reference method). FIL-IDF Standard no. 108:2002/ISO 5764. IDF, Brussels, Belgium.

IDF (International Dairy Federation). 2006. Milk-Enumeration of somatic cells. Part 2: Guidance on the operation of fluoro-optoelectronic counters. FIL-IDF Standard no. 148-2 (E). IDF, Brussels, Belgium.

Martínez, J. R., C. Gonzalo, J. A. Carriedo, and F. San Primitivo. 2003. Effect of freezing on Fossomatic cell counting in ewe milk. J. Dairy Sci. 86:2583-2587.

Pirisi, A., A. Lauret, and J. P. Dubeuf. 2007. Basic and incentive payments for goat and sheep milk in relation to quality. Small Rumin. Res. 68:167-178.

Rasmussen, M. D., M. Bjerring, P. Justesen, and L. Jepsen. 2002 Milk quality on Danish farms with automatic milking systems. J. Dairy Sci. 85:2869-2878.

Raynal-Ljutovac, K., P. Gaborit, and A. Lauret. 2005. The relationship between quality criteria of goat milk, its technological properties and the quality of the final products. Small Rumin. Res. 60:167-177. 
Sánchez, A., D. Sierra, C. Luengo, J. C. Corrales, C. T. Morales, A. Contreras, and C. Gonzalo. 2005. Influence of storage and preservation on Fossomatic cell count and composition of goat milk. J. Dairy Sci. 88:3095-3100.

SAS Institute. 1999. SAS/STAT Software. Changes and enhancements through release 6.11. SAS Inst., Inc., Cary, NC.

Sierra, D., A. Sánchez, C. Luengo, J. C. Corrales, C. T. Morales, A. Contreras, and C. Gonzalo. 2006. Temperature effects on Fossomatic cell counts in goat's milk. Int. Dairy J. 16:385-387.

Slaghuis, B. A. 2001. The freezing point of authentic and original farm bulk tank milk in The Netherlands. Int. Dairy J. 11:121-126.
Szijarto, L., and F. R. van de Voort. 1983. Determination of added water and bovine milk to caprine milk. J. Dairy Sci. 66:620-623.

Thrusfield, M. 1995. Veterinary Epidemiology. 2nd ed. Blackwell Science Publications, Cambridge, UK.

Van Crombrugge, J. M. 2003. Freezing point. Pages 16-22 in New Applications of Mid-infra-red Spectrometry for the Analysis of Milk and Milk Products. Proc. Int. Dairy Fed. Symp. Advancement in Analytical Techniques. Holstebro, Denmark. Bull. IDF 383. International Dairy Federation, Brussels, Belgium.

Wheelock, J. V., J. A. F. Rook, and F. H. Dodd. 1965. The relationship in the cow between the osmotic pressure of milk and of blood. J. Dairy Res. 32:79-88. 